\title{
PENTINGNYA PERAWAT MELAKUKAN DOKUMENTASI \\ PENGKAJIAN YANG AKURAT KEPADA PASIEN BARU
}

\author{
Khairun Nisa Ginting \\ Kahirunnisaginting06@gmail.com
}

\section{LATAR BELAKANG}

Pasien baru merupakan seseorang yang datang ke rumah sakit dengan tujuan untuk mendapatkan pelayanan kesehatan. Dalam hal ini rumah sakit berperan sebagai penyedia layanan kesehatan bagi setiap pasien dan mampu memberikan solusi dalam mengatasi setiap masalah kesehatan pasien. Ketika pasien masuk rumah sakit staf medis khususnya perawat melakukan pengkajian (anamnesis) terhadap pasien mengenai keluhan atau masalahnya. Proses pengkajian merupakan tahap awal dari proses keperawatan yang dilakukan secara sistematis dengan mengumpulkan data individu secara komprehensif terkait aspek biologis, psikologis, sosial, maupun spiritual (Rutami, 2012). Fase dari pengkajian meliputi: pengumpulan data, analisis data, pengelompokan data dan dokumentasi data (Haryanto, 2007).

Dokumentasi pengkajian keperawatan merupakan catatan tentang hasil pengkajian yang dilaksanakan untuk mengumpulkan informasi dari pasien, membuat data dasar tentang pasien, dan membuat catatan tentang respons kesehatan pasien. Pengkajian yang komprehensif atau menyeluruh, sistematis yang logis akan mengarah dan mendukung pada identifikasi masalah-masalah pasien. Masalah-masalah ini dengan menggunakan data penkajian sebagai dasar formulasi yang dinyatakan sebagai diagnosa keperawatan.

Dengan terdapatnya kesadaran diri dari perawat maka akan meningkatkan motivasi perawat dalam melakukan dokumentasi pengkajian asuhan keperawatan. Dengan motivasi diri yang tinggi dan kepatuhan dari seorang perawat maka pencapaian tujuan akan pelaksanaan dokumentasi pengkajian asuhan keperawatan akan dilakukan dengan baik dan meningkatkan pelayanan yang berkualitas dan profesional dalam bidang keperawatan,sehingga perawat perlu memiliki motivasi yang tinggi ketika melakukan 
pendokumentasian dan pengkajian agar dapat memberikan hasil dari dokumentasi keperawatan yang baik.

\section{METODE}

Penelitian ini menggunakan metode penelitian kualitatif fenomenologi dengan pengumpulan data melalui wawancara dan double check. serta Literature review dengan cara menganalisis, kajian dan eksplorasi jurnal, text book, maupun e-book yang relevan dan membahas evaluasi asuhan keperawatan pada pasien baru. Adapun jurnal yang digunakan pada literature review ini adalah jurnal yang diterbitkan dari kurun waktu 10 tahun terakhir didapatkan dengan menggunakan 2 database Portal Garuda dan Google Scholar.

\section{HASIL}

Dari jurnal yang telah dipilih yaitu, jurnal pengalaman perawat dalam melakukan pengkajian pasien baru di rumah sakit swasta di indonesia bagian barat vol.6,no.1.2018, berdasarkan hasil wawancara dapat disimpulkan bahwa perawat melakuan pengkajian pasien baru tidak semua lengkap sesuai format pengkajian. Perawat melakukan pengkajian karena adanya fakto faktor pendorong seperti standar operasional prosudue (SOP), kewajiban perawat bina hubungan saling percaya (BHSP), asuhan keperawatan, untuk mengetahui kondisi pasien dan dokumentasi. Perawat juga memperoleh manfaat dalam melakukan pengkajian pasien baru yaitu dapat mengetahui kondisi pasien, mendekatkan diri kepada pasien dan dapat dilanjutkan proses keperawatan.

Dan Jurnal STIKES Vol. 6 No. 2, Desember 2013, Tahap - tahap proses keperawatan ini memerlukan dokumentasi dari awal sampaiseterusnya. Suatu pengkajian yang komprehensif atau menyeluruh, sistematis, dan logis akanmengarah dan mendukung identifikasi masalah kesehatan klien. Masalah - masalah ini menggunakan data pengkajian sebagai dasar formulasi untuk menegakkan diagnosiskeperawatan. Rencana asuhan keperawatan mencantumkan diagnosis keperawatan,mengomunikasikan pernyataan kriteria hasil yang diharapkan dan dapat diukur, danintervensi keperawatan yang disusun untuk klien. Pengkajian, formulasi, diagnosis, danrencana asuhan keperawatan yang tertulis memberikan perawatan yang berorientasi padatujuan dan perawatan yang konsisten. Perana dokumentasi 
membutuhkan perawat untukmenyiapkan catatan klinis yang merefleksikan pengkajian yang akurat, diagnosiskeperawatan yang spesifik, dan rencana asuhan keperawatan individual.

Dalam melakukan dokumentasi pengkajian oleh perawat Faktor tenaga dan motivasi merupakan faktor yang paling dominan yang mempengaruhi pendokumentasian asuhan keperawatan .Semakin tenaga tidak memadai dan motivasi yang tidak ada akan menurunkan kualitas asuhan keperawatan yang diberikan oleh perawat.

\section{PEMBAHASAN}

Dokumentasi pengkajian keperawatan merupakan bukti pencatatan dan pelaporan yang ditulis oleh perawat mengenai status dan kondisi klien dan digunakan sebagai alat komunikasi yang akurat dan lengkap. Sekarang ini perawat tidak hanya dituntut untuk meningkatkan kualitas asuhan keperawatan tetapi juga dituntut untuk dapat mendokumentasikan secara benar dan baik Tujuan Pendokumentasian yang dilakukan oleh perawat antara lain untuk :

1. Mengkomunikasikan data klien ke semua anggota tim kesehatan sehingga tidak terjadi data yang tumpang tindih dan salah dalam memberikan asuhan keperawatan.

2. Sebagai bukti-bukti untuk tujuan evaluasi hasil dari implementasi asuhan keperawatan

3. Untuk jaminan kepada masyarakat tentang lingkup dan mutu pelayanan keperawatan dan membuktikan pekerjaan perawatan serta meningkatkan tanggung gugat perawat.

4. Sebagai sumber data untuk melakukan penelitian.

Manfaat dari dokumentasi pengkajian keperawatan adalah dimana dokumentasi pengkajian keperawatan yang berisi semua catatan tentang informasi klien dan merupakan dokumentasi dan pengkajian yang resmi yang bernilai hukum. jika perawat mengalami suatu masalah yang berhubungan dengan profesi keperawatan, dimana peran perawat sebagai pemberi jasa dan klien sebagai pengguna jasa maka dokumentasi sangat diperlukan. Dokumentasi dan pengkajian dapat dijadikan barang bukti di pengadilan sebagai bukti. Maka dari itu data klien harus di identifikasi secara lengkap, jelas dan objektif dan ditandatangani oleh perawat, nama jelas, tanggal, perlunya penulisan dengan jelas agar tidak menimbulkan salah interpretasi. Pencatatan data klien yang dilakukan dengan lengkap dan akurat akan memberikan kemudahan bagi perawat dalam membantu menyelesaikan masalah yang dialami 
oleh klien. Selain itu untuk mengetahui sejauh mana masalah yang dialami oleh klien untuk dapat diatasi dan seberapa jauh masalah baru dapat di identifikasi dan di monitor melalui catatan yang akurat, hal ini akan membantu meningkatkan mutu keperawatan.

Jenis dokumentasi keperawatan meliputi:

1. Dokumentasi pada saat pengkajian awal (InitialAssessment) Dokumentasi yang dibuat ketika pasien pertama kali masuk rumah sakit. Data yang dikaji pada pasien berupa data awal yang digunakan sebagai dasar dalam pemberian asuhan keperawatan.

2. Dokumentasi pengkajian lanjutan (Ongoing Assessment) Data pada dokumentasi ini merupaka pengembangan dasar yang dilakukan untuk melengkapi pengkajian awal dengan tujuan semua data menjadi lengkapsehingga mendukung infromasi tentang permasalahan kesehatan pasien. Hasil pengkajian ini dimasukkan dalam catatan perkembangan terintegrasi pasien atau pada lembar data penunjang.

3. Dokumentasi pengkajian ulang (Reassessment) Dokumentasi ini merupakan pencatatan terhadap hasil pengkajian yang didapat dari informasi selama evluasi. Perawat mengevauasi kemajuan dta terhadap pasien yang sudah ditentukan

Dalam pengkajian keperawatan terdapat jenis data yang dapat diperoleh, yaitu:

\section{Data subjektif}

Data subjektif diperoleh dari hasil pengkajian terhadap pasien dengan teknik wawancara, keluarga, konsultan, dan tenaga kesehatan lainnya serta riwayat keperawatan. Data ini berupa keluhan atau persepsi subjektif pasien terhadap status kesehatannya.

\section{Data Objektif}

Informasi data objektif diperoleh dari hasil observasi, pemeriksaan fisik, hasil pemeriksaan penunjang dan hasil laboratorium. Fokus dari pengkajian data objektif berupa status kesehatan, pola koping, fungsi status respons pasien terhadap terapi, risiko untuk masalah potensial, dukungan terhadap pasien. Karakteristik data yang diperoleh dari hasil pengkajian seharusnya memiliki karakteristik yang lengkap, akurat, nyata dan relevan. Data yang lengkap mampu mengidentifikasi semua masalah keperawatan pada pasien. 
Dokumentasi pengkajian keperawatan adalah sebuah alat perekam terhadap masalah yang berkaitan dengan klien. Perawat atau tenaga kesehatan lain akan bisa melihat catatan yang ada dan sebagai alat komunikasi yang dijadikan pedoman dalam pemberian asuhan keperawatan kepada klien.

Berdasarkan daftar pertanyaan hasil wawancara pada penelitian yang dilakukan oleh Rutami \& Setiawan (2012) tentang "Pelaksanaan Proses Pengkajian Keperawatan di Ruang Rawat Inap RSUP H. Adam Malik Medan" ditemukan lima tema besar mengenai pengalaman perawat dalam melakukan pengkajian pasien baru yaitu :

1) pengalaman perawat melakukan proses keperawatan;

2) pengalaman melakukan pengkajian pasien baru;

3) faktor pendorong melakukan pengkajian pasien baru;

4) manfaat melakukan pengkajian pasien baru;

5) hambatan dalam melakukan pengkajian pasien baru.

Di samping itu berdasarkan hasil wawancara dengan enam partisipan ditemukan kategori-kategori yang mendukung tema tersebut. Hasil penelitian ini menunjukan bahwa terdapat lima tema terkait pengalaman perawat dalam melakukan pengkajian pasien baru. Lima tema tersebut yaitu pengalaman melakukan proses keperawatan, melakukan pengkajian pasien baru, serta faktor pendorong dalam melakukan pengkajian, manfaat yang diperoleh dan hambatan dalam melakukan pengkajian. Jumlah kategori dari lima tema tersebut yaitu 16 kategori. Hasil wawancara menunjukan bahwa dalam melakukan proses keperawatan partisipan melakukannya sesuai tahapan dan melakukannya untuk mendapatkan sumber data. Dalam melakukan pengkajian pasien baru, partisipan melakukannya dengan mengikuti pedoman lembar asesmen awal yang sudah ada. Berdasarkan double check dengan dokumen ditunjukan bahwa benar semua pengkajian terisi hingga pada pengkajian aspek biologis, psikologis, sosial, maupun spiritual.

Pengkajian keperawatan, seperti yang telah dijelaskan sebelumnya, memerlukan pengum pulan dan pengorganisasian data yang sistematis, dan mengorganisasi data yangmenjelaskan respon klien terhadap masalah - masalah kesehatan. Tujuan dari pendokumentasian data pengkajian keperawata adalah sebagai berikut. 
1. Untuk mengidentifikasi kebutuhan dan respon klien yang unik terhadap masalah masalah dan akan ditegakkan menjadi diagnosis keperawatan yang mempengaruhi rencana intervensikeperawatan yang diperlukan.

2. Untuk menggabungkan dan mengorganisasi data dan beberapa sumber yang dikumpulkan menjadi satu sehingga masalah kesehatan klien dapat dianalisis dan diidentifikasi.

3. Untuk meyakinkan garis dasar informasi yang ada dan untuk bertindak sebagai poinreferensi dalam mengukur perubahan yang terjadi pada kondisi kesehatan klien.

4. Untuk mengidentifikasikan definisi karakteristik sesuai respon dan kondisi kesehatan klienyang akan memengaruhi rencana dan pemberian intevensi keperawatan.

5. Untuk menyuplai data yang cukup guna memberikan intervensi keperawatan yang sesuaidengan kebutuhan klien.

6. Untuk memberikan dasar guna penulisan rencana asuhan keperawatan yang efektif.

Untuk mencapai tujuan - tujuan ini, maka perawat menggunakan semua informasitentang klien yang diperoleh dari wawancara klien, riwayat kesehatan, pemeriksaan fisik,labolatorium, dan diagnostik lainnya. Pengkajian harus lengkap dan seakurat mungkin.Pengumpulan data untuk kelengkapan informasi status kesehatan atau masalah klien harusterus-menerus dilakukan untuk mengidentifikasi masalah-masalah baru dan mengubah prioritas klinis.

Dengan demikian dapat dijelaskan bahwa ketersediaan format dokumentasi pengkajian keperawatan berpengaruhi terhadap pelaksanaan dokumentasi.

\section{PENUTUP}

Pendokumentasian dalam proses keperawatan merupakan hal yang sangat penting, namun didalam prakteknya masih banyak ditemukan hambatanhambatan yang mengakibatkan pendokumentasian belum baik dan sempurna. Kurang patuhnya perawat akan berakibat terhadap rendahnya mutu asuhan keperawatan ,disarankan untuk dapat memperbaiki ketenagaan, mempertahankan dan meningkatkan motivasi perawat dalam melaksanakan pendokumentasian proses keperawatan agar proses pendokumentasian berjalan dengan baik . Dokumentasi yang dilakukan oleh perawat memiliki fungsi sebagai bukti bagi perawat telah melakukan tindakan yang dilakukannya. 


\section{DAFTAR PUSTAKA}

Dalami, E. (2011). Dokumentasi Keperawatan Dengan Kurikulum Berbasis Kompetensi. Jakarta : Trans Info Media

Efendy, M. (2012). Perbedaan Tingkat Kualitas Dokumentasi Proses Keperawatan Sebelum Dan Sesudah Penerapan NANDA-I, NIC, Dan NOC. Jurnal Keperawatan Soedirman, 7(2), 67-77.

Hsm, D. (2010). Improving the quality of nursing documentation on an acute medicine unit

Ivo, G., Manik, M., \& Simamora, O. (2018). Pengalaman perawat dalam melakukan pengkajian pasien baru di satu rumah sakit swasta di indonesia bagian barat. Nursing Current . 6(1), 29-31.

Lestari, A. S., Sulisnadewi, N. L. K., \& I Wayan, S. ( 2007). Hubungan Tingkat Pengetahuan Perawat dengan Pelaksanaan Dokumentasi Proses Keperawatan di RSUP Sanglah Denpasar. Universitas Udayana: Bali.

Marrelli, T. M. (2008). Buku saku dokumentasi keperawatan. EGC.

Nursalam, (2009). Proses dan Dokumentasi Keperawatan Edisi 2. Jakarta : Salemba Medika.

Priharjo, Robert (2012). Pengkajian Fisik Keperawatan: konsep, proses dan praktek. Volume 2. Edisi 4. Jakarta : EGC

Sari, D. P., \& Siwi, G. R. (2019). Hubungan Antara Pengetahuan Perawat Tentang Rekam Medis dan Dokumentasi Keperawatan Dengan Kelengkapan Pencatatan Dokumentasi Keperawatan di Klinik MTA Surakarta 2019. Infokes Journal, 9(1), 45- 49.

Simamora, R. H. (2019). Development of Guidelines for Applying appropriate Patient Identification to Achieve Patient Safety Goal INC2019 12th International Nursing Conference. 2019.10455 - 455 (1 pages) UCI(KEPA) : I410-ECN-0101-2019-512001224337

Simamora. R. H. (2008) The correlation of ward chief's giving direction and command and the performance of on-duty nurses at Jember dr. Subandi general hospital inpatient wards. jurnal Administrasi dan Kebijakan Kesehatan, (https://fkm.unair.ac.id/jurnal-administr)

Yunartha, M. (2017). Pelaksanaan Pendokumentasian Asuhan Keperawatan di RS Jiwa Daerah Provinsi Jambi. Scientia Journal, 4(3), 265-272. 